\title{
Phytoplankton diversity and its relation to the physicochemical parameters in main water bodies of Vinh Long province, Vietnam
}

\author{
Đa dạng thực vật phù du và mối liên quan của nó với các thông số hóa lý ở các thủy vực \\ chính trên địa bàn tỉnh Vinh Long, Việt Nam
}

\author{
LE, Thi Trang*; PHAN, Doan Dang; HUYNH, Bao Dang Khoa; LE, Van Tho; NGUYEN, Van Tu \\ Institute of Tropical Biology, Vietnam Academy of Science and Technology, 85 Tran Quoc Toan street, District 3, Ho Chi Minh City, Vietnam
}

\begin{abstract}
Phytoplankton samples were collected in 2016 during the dry and rainy seasons at nine sampling sites in Vinh Long province, Vietnam. Some basic environment parameters such as temperature, $\mathrm{pH}$, dissolved oxygen, nitrate and phosphate were measured and a total of 209 phytoplankton species (six phyla, 96 genera) were identified. The phylum that had the greatest number of species was Bacillariophyta ( 82 species), followed by Chlorophyta (61 species), Cyanophyta (39 species), Euglenophyta (21 species), Chrysophyta (three species) and Dinophyta (three3 species). The phytoplankton density ranged from 4,128 to 123,029 cells/liter. The dominant algae recorded in the study area include Microcystis aeruginosa, Merismopedia g/auca, Oscillatoria perornata, Jaaginema sp., Planktothrix agardhii, Coscinodiscus subtilis, Melosira granulata. In particular, Microcystis aeruginosa was the most density dominant species in the total number of sampling sites during the dry season survey, and this species was classified as a group producing toxins harmful to the environment. Surface water quality, according to QCVN 08: 2015/BTNMT was classified into Column A1 for pH, nitrate and Column B1 for dissolved oxygen, and Column B2 for phosphate. Phytoplankton community structure and environmental factors changed substantially between dry and rainy seasons. A Pearson ( $r$ ) correlation coefficient was used for the relative analysis. The results indicated that the number of phytoplankton species were a significantly positive correlation with $\mathrm{pH}$, dissolved oxygen and nitrate in the rainy season. The phytoplankton abundance was uncorrelated with environmental factors in both seasons.
\end{abstract}

\begin{abstract}
Các mẫu thực vật phù du được thu thập trong năm 2016 (mùa khô và mùa mưa) tại 9 vị trí ở tỉnh Vinhh Long, Việt Nam. Một số thông số môi trường như nhiệt độ, pH, oxy hòa tan, nitrat và phốt phát được đo ngay tại hiện trường. Tổng cộng 209 loài thực vật phù du được ghi nhận (6 ngành, 96 chi). Số lượng loài cao nhất là tảo Silic (82 loài), kế đến là tảo Lục (61 loài), tảo Lam (39 loài), tảo Mắt (21 loài), tảo Vàng ánh (3 loài) và tảo Giáp(3 loài). Mật độ thực vật phù du dao động từ 4.128 đến 123.029 tếbào/ lít. Các loài ưu thế ghi nhận được ở khu vực nghiên cứu gồm có: Microcystis aeruginosa, Merismopedia glauca, Oscillatoria perornata, Jaaginema sp., Planktothrix agardhii; Coscinodiscus subtilis, Melosira granulata. Trong đó, loài Microcystis aeruginosa chiếm ưu thế nhiều nhất trên tổng số điểm thu mẫu trong đợt khảo sát mùa khô, đồng thời loài này được xếp vào nhóm sản sinh độc tố gây hại cho môi trường. Chất lượng nước mặt theo QCVN 08:2015/BTNMT được xếp vào loại A1 đối với thông số pH, nitrat và loại B1 đối với thông số oxy hòa tan, và loại B2 đối với phốt phát. Cấu trúc quần xã thực vât nổi và các yếu tố môi trường thay đổi đáng kể giữa mùa mưa và mừa khô. Hệ số tương quan Pearson (r) được dùng để phân tích. Kết quả cho thấy số lượng thực vật phù du có tương quan thuận với pH, oxy hòa tan và nitrat trong mùa mưa và có ý nghĩa về mặt thống kê. Mật độ của thực vật phù du không tương quan với các yếu tố môi trường trong cả hai mùa.
\end{abstract}

Keywords: correlation coefficient of Pearson (r), diversity, phytoplankton, physicochemical factors

\section{Introduction}

Vinh Long province is located in the downstream of Mekong river, Vietnam. It is situated between the Tien and Hau rivers, in the center of the Mekong Delta, $136 \mathrm{~km}$ far from Ho Chi Minh City to the north, $40 \mathrm{~km}$ from Can Tho city to the south with geographic coordinates from 9 ${ }^{\circ} 5^{\prime} 45^{\prime \prime}$ to $10^{\circ} 19^{\prime} 50^{\prime \prime} \mathrm{N}$ and $104^{\circ} 41^{\prime} 25^{\prime \prime}$ to $106^{\circ} 17^{\prime} 00^{\prime \prime} \mathrm{E}$. The area includes not only dense river networks but also a complex natural water distribution system with abundant water resources, which are favorable for the distribution and development of many aquatic species.

Phytoplankton was the primary producer and held a significant role in an aquatic food chain, playing an essential role in retaining the stability and integrity of the aquatic ecological system (Long et al., 2013). Phytoplankton is one of the important biological tools used for the assessment of the 
biological water quality status in water bodies due to its sensitivity to any change in the environment (Salman et al., 2013; Luong and Phan, 2014).

In this study, we investigated the phytoplankton composition, abundance, and dominant species of phytoplankton communities in both dry and rainy seasons of 2016 in the main water bodies of Vinh Long province, Vietnam. Additionally, the relationship between phytoplankton community and environmental factors is also discussed.

\section{Materials and methods}

The current study was carried out in dry (March) and rainy (September) seasons of 2016. The samples were collected at nine sites in main water bodies of Vinh Long province (Figure 1).

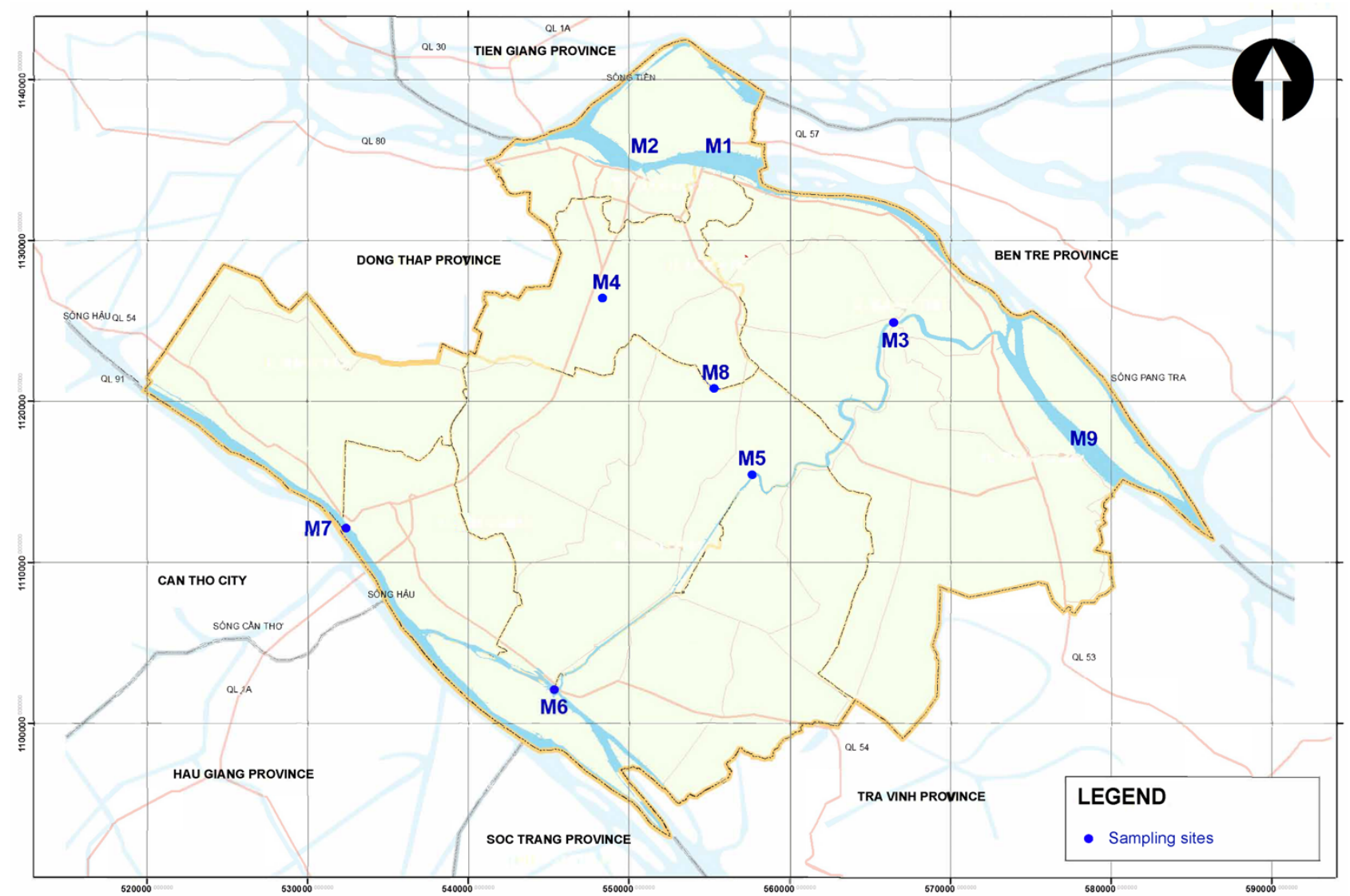

Figure 1. Map showing sampling stations in Vinh Long

The water temperature, $\mathrm{pH}$ and dissolved oxygen were measured in situ by HANA HI9828/4 multi-indicator machine. The nitrate and phosphate were analyzed in the laboratory according to APHA methods (2005). The water quality assessment by QCVN 08:2015/BTNMT is used to indicate the overall water quality conditions.

Phytoplankton samples were collected at nine sites using plankton net and preserved in 5\% neutralized formalin. The samples were studied under microscope at 100 - 400X magnification (Olympus BX51 microscope). The identification was based on morphology following the identification books of Desikachary (1959) and Nguyen et al. (2007) for Cyanophyta; Shirota (1966), and Truong (1993) for Bacillariophyta; Duong and Vo (1997), Thompson (1959) for Chlorophyta and other taxonomy books for Chrysophyta, Euglenophyta, and Dinophyta. A Sedgewick Rafter counting chamber was used to determine the phytoplankton density. The phytoplankton classification system is arranged according to the AlgaeBase taxonomic system (Guiry \& Guiry, 2016).

The correlation between the physicochemical parameters and the phytoplankton population was estimated using the Pearson correlation coefficient method and also tested for statistical significance at 5\% level. The one-way analysis of variance (ANOVA) was used to analyze the differences of species' composition as well as the phytoplankton density among sampling sites and between two seasons. This statistical analysis was performed using Excel 2010 software.

\section{Results}

\subsection{Environmental characteristics}

The average physicochemical concentrations of water in the dry and wet seasons is showed in Table 1. The seasonal fluctuations in the temperature varied from 26.8 to $31.3^{\circ} \mathrm{C}$ 
with the minimum achieved during the rainy season and the maximum during the dry season. The mean seasonal $\mathrm{pH}$ values ranged from 7.1 to 8.2. The concentration of dissolved oxygen in surface water was from 3.1 to $5.3 \mathrm{mg} / \mathrm{L}$.
The nitrate concentration varied between 0.18 and 0.48 $\mathrm{mg} / \mathrm{L}$, phosphate fluctuated from 0.59 to $1.14 \mathrm{mg} / \mathrm{L}$ with minimum during dry and maximum during rainy seasons.

Table 1. Physical-chemical water parameters measured in the studied area during the dry and rainy seasons of 2016

\begin{tabular}{|c|c|c|c|c|c|c|}
\hline \multirow[t]{2}{*}{ Parameters } & \multicolumn{3}{|c|}{ Dry season } & \multicolumn{3}{|c|}{ Rainy season } \\
\hline & Min & Max & Mean \pm SD & Min & Max & Mean \pm SD \\
\hline Temperature $\left({ }^{\circ} \mathrm{C}\right)$ & 28.9 & 31.3 & $29.9 \pm 0.7$ & 26.8 & 29.6 & $28.5 \pm 0.9$ \\
\hline $\mathrm{pH}$ & 7.2 & 7.9 & $7.6 \pm 0.2$ & 7.1 & 8.2 & $7.6 \pm 0.3$ \\
\hline Dissolved oxygen (mg/L) & 3.5 & 5.2 & $4.3 \pm 0.6$ & 3.1 & 5.3 & $4.2 \pm 0.6$ \\
\hline Nitrate (mg/L) & 0.18 & 0.48 & $0.28 \pm 0.09$ & 0.19 & 0.46 & $0.29 \pm 0.07$ \\
\hline Phosphate (mg/L) & 0.59 & 1.06 & $0.851 \pm 0.165$ & 0.64 & 1.14 & $0.86 \pm 0.16$ \\
\hline
\end{tabular}

\subsection{The characteristics of phytoplankton communities}

\subsubsection{The structure of phytoplankton community}

A total of 209 phytoplankton species belonging to six divisions, 13 classes, 34 orders, 61 families and 96 genera were recorded. Among the phytoplankton groups, 82 species belonging to 33 genera in Bacillariophyta represented approximately $39.2 \%$ of the total species, 61 species belonging to 32 genera in Chlorophyta represented 29.2\% and 39 species belonging to 21 genera in Cyanophyta represented $18.7 \%$. In addition, the samples included 21 species belonging to five genera in Euglenophyta, three species belonging to three genera in Chrysophyta and three species belonging to two genera in Dinophyta. The number of phytoplankton species was greater in the wet season.
An increase in Euglenophyta and Chlorophyta species occurred in the rainy season, when 12 and 25 species were found, respectively. In contrast, a decrease in Bacillariophyta was found, when four species disappeared. The phytoplankton composition in Vinh Long is showed in Table 2.

Most of the algal species and genera recorded in Vinh Long (such as Microcystis, Anabaena, Oscillatoria, Cyclotella, Navicula, Eunotia, Pediastrum, Pandorina, Closterium, Scenedesmus, Staurastrum, Euglena, Phacus, Trachelomonas, Strombomonas etc.) characterize freshwater bodies. In addition, some of the species like Coscinodiscus, Biddulphia, Surirella, Chaetoceros, Gyrosigma originated from the estuary or coastal regions. This proves that the aquatic environment in the studied area was co-affected by freshwater from inland and by seawater via the tide.

Table 2. Composition of phytoplankton species collected in Vinh Long

\begin{tabular}{|c|c|c|c|c|c|c|c|}
\hline No. & Taxa & $\begin{array}{l}\text { Dry } \\
\text { season }\end{array}$ & $\begin{array}{l}\text { Rainy } \\
\text { season }\end{array}$ & No. & Taxa & $\begin{array}{l}\text { Dry } \\
\text { season }\end{array}$ & $\begin{array}{l}\text { Rainy } \\
\text { season }\end{array}$ \\
\hline & Phylum Cyanophyta & & & 106 & Pleurosigma angulatum & + & + \\
\hline 1 & Anabaena affinis & + & & 107 & Rhizosolenia setigera & + & \\
\hline 2 & Anabaena circinalis & + & + & 108 & Skeletonema costatum & + & \\
\hline 3 & Anabaena sp. & + & + & 109 & Stauroneis anceps & & + \\
\hline 4 & Anabaenopsis raciborskii & + & & 110 & Synedra ulna & + & + \\
\hline 5 & Arthrospira sp. & + & + & 111 & Surirella biseriata & + & + \\
\hline 6 & Aphanizomenon aphanizomenoides & + & + & 112 & Surirella elegans & + & + \\
\hline 7 & Aphanocapsa sp. & + & + & 113 & Surirella gemma & + & + \\
\hline 8 & Chroococcus sp. & & + & 114 & Surirella minuta & + & + \\
\hline 9 & Jaaginema sp. & + & + & 115 & Surirella robusta & + & + \\
\hline 10 & Geitlerinema splendidum & + & + & 116 & Surirella ovata & + & + \\
\hline 11 & Gomphosphaeria lacustris & & + & 117 & Surirella tenera & & + \\
\hline 12 & Komvophoron schmidlei & + & & 118 & Trachyneis debyi & & + \\
\hline 13 & Lyngbya birgei & + & + & 119 & Thalassionema nitzschioides & + & \\
\hline 14 & Lyngbya martensiana & + & + & 120 & Triceratium alternans & + & + \\
\hline 15 & Lyngbya sp. & & + & 121 & Triceratium favus & + & + \\
\hline 16 & Merismopedia g/auca & + & + & 122 & Trieres mobiliensis & + & \\
\hline 17 & Merismopedia punctata & + & + & 123 & Trieres regia & + & \\
\hline 18 & Microcoleus lacustris & & + & 124 & Vanheurckia lewisiana & + & + \\
\hline 19 & Microcystis aeruginosa & + & + & & Phylum Chlorophyta & & \\
\hline 20 & Microcystis botrys & + & & 125 & Actinastrum hantzschii & + & + \\
\hline
\end{tabular}




\begin{tabular}{|c|c|c|c|c|c|c|c|}
\hline No. & Taxa & $\begin{array}{l}\text { Dry } \\
\text { season }\end{array}$ & $\begin{array}{l}\text { Rainy } \\
\text { season }\end{array}$ & No. & Taxa & $\begin{array}{l}\text { Dry } \\
\text { season }\end{array}$ & $\begin{array}{l}\text { Rainy } \\
\text { season }\end{array}$ \\
\hline 21 & Microcystis flos - aquae & + & + & 126 & Ankistrodesmus arcuatus & & + \\
\hline 22 & Microcystis panniformis & + & + & 127 & Ankistrodesmus gracilis & & + \\
\hline 23 & Microcystis protocystis & + & + & 128 & Ankistrodesmus longissimus & + & \\
\hline 24 & Microcystis wesenbergii & + & + & 129 & Coelastrum reticulatum & & + \\
\hline 25 & Oscillatoria acuta & + & + & 130 & Coelastrum microporum & & + \\
\hline 26 & Oscillatoria curviceps & & + & 131 & Closterium gracile & & + \\
\hline 27 & Oscillatoria limosa & + & & 132 & Closterium macilentum & + & + \\
\hline 28 & Oscillatoria perornata & + & + & 133 & Closterium intermedium & + & + \\
\hline 29 & Oscillatoria princeps & + & + & 134 & Closterium moniliferum & + & + \\
\hline 30 & Oscillatoria tenuis & + & + & 135 & Closterium kuetzingii & & + \\
\hline 31 & Oscillatoria sp. & + & + & 136 & Closterium sp. & + & + \\
\hline 32 & Planktothrix agardhii & + & + & 137 & Cosmarium debaryi & & + \\
\hline 33 & Phormidium chalybeum & + & + & 138 & Cosmarium obsoletum & & + \\
\hline 34 & Phormidium sp. & + & & 139 & Cosmarium sp. & & + \\
\hline 35 & Pseudanabaena mucicola & + & + & 140 & Crucigenia fenestrata & + & \\
\hline 36 & Raphidiopsis curvata & + & + & 141 & Crucigeniella rectangularis 4 & + & \\
\hline 37 & Snowella rosea & + & & 142 & Crucigenia lauterbornii & & + \\
\hline 38 & Spirulina major & + & + & 143 & Desmidium baileyi & & + \\
\hline \multirow[t]{2}{*}{39} & Spirulina princeps & & + & 144 & Desmidium sp. & & + \\
\hline & Phylum Chrysophyta & & & 145 & Dictyosphaerium pulchellum & & + \\
\hline 40 & Dinobryon sertularia & & + & 146 & Eudorina elegans & + & + \\
\hline 41 & Mallomonas sp. & & + & 147 & Euastrum spinulosum & & + \\
\hline \multirow[t]{2}{*}{42} & Synura adamsii & & + & 148 & Euastrum sp. & & + \\
\hline & Phylum Bacillariophyta & & & 149 & Gonatozygon aculeatum & & + \\
\hline 43 & Achnanthes brevipes & & + & 150 & Gonium pectorale & & + \\
\hline 44 & Actinoptychus annulatus & + & & 151 & Hyalotheca dissiliens & & + \\
\hline 45 & Actinoptychus trilingulatus & + & + & 152 & Kirchneriella obesa & & + \\
\hline 46 & Amphipleura sp. & & + & 153 & Micrasterias foliacea & & + \\
\hline 47 & Aulacoseira granulata & + & + & 154 & Mougeotia sp. & & + \\
\hline 48 & Bacteriastrum hyalinum & + & & 155 & Scenedesmus acuminatus & + & + \\
\hline 49 & Bacillaria paxillifera & + & + & 156 & Scenedesmus arcuatus & + & \\
\hline 50 & Biddulphia biddulphiana & + & + & 157 & Scenedesmus denticulatus & + & + \\
\hline 51 & Campylodiscus daemelianus & + & + & 158 & Scenedesmus quadricauda & + & + \\
\hline 52 & Campylodiscus undulatus & + & & 159 & Tetrastrum elegans & + & \\
\hline 53 & Climacosphenia moniligera & + & + & 160 & Oedogonium crispum & + & + \\
\hline 54 & Chaetoceros Iorenzianus & + & & 161 & Oocystis borgei & & + \\
\hline 55 & Chaetoceros diversus & + & & 162 & Pandorina morum & + & + \\
\hline 56 & Coscinodiscus asteromphalus & + & + & 163 & Pediastrum boryanum & + & + \\
\hline 57 & Coscinodiscus concinnus & + & + & 164 & Pediastrum simplex & + & + \\
\hline 58 & Coscinodiscus excentricus & + & + & 165 & Pediastrum duplex & + & + \\
\hline 59 & Coscinodiscus gigas & + & + & 166 & Pediastrum tetras & + & + \\
\hline 60 & Coscinodiscus jonesianus & + & + & 167 & Planktosphaeria gelatinosa & + & \\
\hline 61 & Coscinodiscus lineatus & + & + & 168 & Pleurotaenium coronatum & & + \\
\hline 62 & Coscinodiscus marginatus & & + & 169 & Pleurotaenium nodosum & & + \\
\hline 63 & Coscinodiscus radiatus & + & + & 170 & Pleodorina californica & + & \\
\hline 64 & Coscinodiscus rothii & + & + & 171 & Spirogyra ionia & + & + \\
\hline 65 & Coscinodiscus subtilis & + & + & 172 & Spirogyra protecta & & + \\
\hline 66 & Cyclotella comta & + & + & 173 & Spirogyra sp. & + & + \\
\hline 67 & Cyclotella meneghiniana & + & + & 174 & Sphaerocystis schroeteri & & + \\
\hline 68 & Cylindrotheca closterium & + & & 175 & Stigeoclonium tenue & + & + \\
\hline 69 & Cymbella cistula & + & & 176 & Staurastrum arctiscon & & + \\
\hline 70 & Cymbella lanceolata & + & + & 177 & Staurastrum indentatum & & + \\
\hline 71 & Cymbella tumida & + & + & 178 & Staurastrum gracile & & + \\
\hline 72 & Cymbella sp. & & + & 179 & Staurastrum leptocladum & & + \\
\hline 73 & Cymatopleura elliptica & & + & 180 & Staurastrum natator & & + \\
\hline
\end{tabular}




\begin{tabular}{|c|c|c|c|c|c|c|c|}
\hline No. & Taxa & $\begin{array}{l}\text { Dry } \\
\text { season }\end{array}$ & $\begin{array}{l}\text { Rainy } \\
\text { season }\end{array}$ & No. & Taxa & $\begin{array}{l}\text { Dry } \\
\text { season }\end{array}$ & $\begin{array}{l}\text { Rainy } \\
\text { season }\end{array}$ \\
\hline 74 & Diploneis elliptica & & + & 181 & Staurastrum sp. & + & + \\
\hline 75 & Ditylum brightwellii & + & & 182 & Tetraëdron incus & & + \\
\hline 76 & Eunotia rabenhorstianum & + & + & 183 & Tetraëdron gracile & & + \\
\hline 77 & Eunotia pectinalis & + & + & 184 & Volvox aureus & + & + \\
\hline 78 & Eunotia sp. & + & + & 185 & Ulothrix zonata & + & \\
\hline 79 & Fragilaria sp. & + & + & & Phylum Euglenophyta & & \\
\hline 80 & Gomphonema angustatum & + & + & 186 & Euglena acus & + & + \\
\hline 81 & Gyrosigma acuminatum & + & + & 187 & Euglena deses & & + \\
\hline 82 & Gyrosigma balticum & + & + & 188 & Euglena gracilis & + & + \\
\hline 83 & Gyrosigma sinensis & + & + & 189 & Euglena oxyuris & + & + \\
\hline 84 & Gyrosigma wormleyi & + & + & 190 & Euglena viridis & & + \\
\hline 85 & Gyrosigma sp. & + & + & 191 & Euglena spirogyra & & + \\
\hline 86 & Hydrosera triquetra & + & + & 192 & Euglena sp. & & + \\
\hline 87 & Melosira moniliformis & + & + & 193 & Lepocinclis ovum & + & + \\
\hline 88 & Melosira varians & + & + & 194 & Lepocinclis salina & & + \\
\hline 89 & Melosira sp. & + & + & 195 & Phacus anomalus & & + \\
\hline 90 & Navicula cryptocephala & + & + & 196 & Phacus hamatus & & + \\
\hline 91 & Navicula placentula & + & + & 197 & Phacus helikoides & & + \\
\hline 92 & Navicula radiosa & + & + & 198 & Phacus longicauda & & + \\
\hline 93 & Navicula sp. & & + & 199 & Phacus ovalis & & + \\
\hline 94 & Nitzschia longissima & + & + & 200 & Phacus pleuronectes & + & + \\
\hline 95 & Nitzschia lorenziana & + & + & 201 & Phacus trapezoides & + & \\
\hline 96 & Nitzschia parvula & + & & 202 & Phacus tortus & & + \\
\hline 97 & Nitzschia palea & + & & 203 & Phacus sp. & & + \\
\hline 98 & Nitzschia plana & + & + & 204 & Strombomonas sp. & + & + \\
\hline 99 & Nitzschia sigma & + & + & 205 & Trachelomonas hispida & + & + \\
\hline 100 & Nitzschia sigmoidea & + & + & 206 & Trachelomonas sp. & & + \\
\hline 101 & Paralia sulcata & & + & & Phylum Dinophyta & & \\
\hline 102 & Odontella aurita & & + & 207 & Ceratium hirundinella & + & + \\
\hline 103 & Pinnularia braunii & + & & 208 & Peridinium cinctum & & + \\
\hline 104 & Pinnularia gibba & + & + & 209 & Peridinium sp. & + & + \\
\hline 105 & Pinnularia major & + & + & \multicolumn{2}{|c|}{ Total species } & 141 & 177 \\
\hline
\end{tabular}

\subsubsection{Phytoplankton densities}

Phytoplankton density fluctuated from 4,128 to 123,029 cells $/ L$, with maximum measured at the $M 4$ site in the dry season and minimum at the M3 site in the rainy season (Figure 2). The average algal cell densities in Vinh Long were 33,526 cells/L in dry and 12,823 cells/L in wet season. The distribution of algal cell densities in the dry season was higher than in the rainy season. In both seasons, the Cyanophyta group was dominant in terms of cell density (80\%), followed by Bacillariophyta and Chlorophyta. The phytoplankton density was high, being a rich food source for the larvae, crustaceans, zooplankton, shrimp, fish, and bivalve.

The dominant species in the surveyed area were Microcystis aeruginosa, Merismopedia glauca, Oscillatoria perornata, Jaaginema sp., Planktothrix agardhii (belonging to Cyanophyta), Coscinodiscus subtilis, Melosira granulata (belonging to Bacillariophyta). Microcystis aeruginosa contributed the most to phytoplankton abundance during the dry season. 


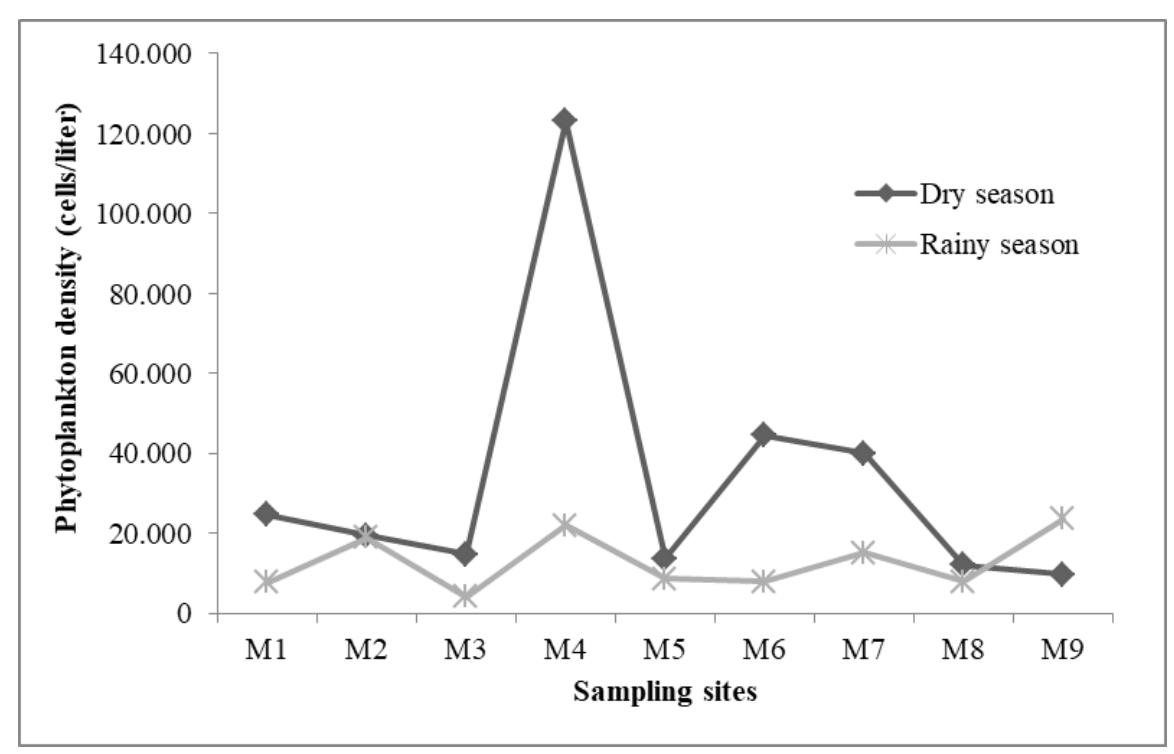

Figure 2. The temporal and seasonal distributions of phytoplankton density in Vinh Long

\subsubsection{The phytoplankton communities in relation to environmental factors in main water bodies, Vinh Long province}

The relation between phytoplankton communities and the environmental factors is showed in Table 3.

Table 3. Correlation between phytoplankton (species number, abundance) and environmental parameters in Vinh Long based on Pearson correlation test.

\begin{tabular}{lrrrrrrrr}
\hline \multirow{2}{*}{ Variables } & \multicolumn{3}{c}{ Dry season } & \multicolumn{3}{c}{ Rain season } \\
\cline { 2 - 9 } & \multicolumn{2}{c}{ Species number } & \multicolumn{2}{c}{ Abundance } & \multicolumn{2}{c}{ Species number } & \multicolumn{2}{c}{ Abundance } \\
\cline { 2 - 9 } & $\mathbf{r}$ & $\mathbf{p}$ & $\mathbf{r}$ & $\mathbf{p}$ & $\mathbf{r}$ & $\mathbf{p}$ & $\mathbf{r}$ & $\mathbf{p}$ \\
\hline Temperature & 0.261 & 0.498 & 0.211 & 0.586 & -0.473 & 0.198 & 0.035 & 0.992 \\
$\mathrm{pH}$ & 0.224 & 0.561 & 0.095 & 0.808 & 0.859 & $0.002^{*}$ & 0.23 & 0.551 \\
$\mathrm{DO}$ & -0.386 & 0.304 & -0.166 & 0.669 & 0.694 & $0.037^{*}$ & 0.3 & 0.432 \\
$\mathrm{~N}-\mathrm{NO}_{3}{ }^{3}$ & 0.025 & 0.948 & 0.174 & 0.653 & 0.683 & $0.042^{*}$ & 0.578 & 0.102 \\
$\mathrm{P}_{-} \mathrm{PO}_{4}{ }^{-}$ & -0.262 & 0.494 & 0.05 & 0.897 & -0.228 & 0.553 & -0.555 & 0.120 \\
\hline
\end{tabular}

*Correlation is significant at the 0.05 level

The statistical data treatment indicated that species number of phytoplankton were in significantly positive correlation with $\mathrm{pH}(r=0.859, \mathrm{p}<0.05)$, dissolved oxygen $(r=0.694$, $p<0.05)$, and nitrate $(r=0.683, p<0.05)$ in the rainy season. Contrary to our expectation, the number of species in the dry season and the number of individuals in both of the seasons were not correlated with any monitored environmental factors.

\section{Discussion}

The average temperature of the main water bodies in Vinh Long province ranged from 28.5 to $29.9^{\circ} \mathrm{C}$ which was similar to the water temperature of some other water bodies in Southern Vietnam. This temperature offered favorable conditions for the development of phytoplankton (Dao \& Bui, 2016). The environmental parameters of such as $\mathrm{pH}$, dissolved oxygen, nitrate, phosphate were investigated and compared to the National technical regulation on surface water quality QCVN 08:2015/BTNMT. The values of pH and nitrate were lower than the standard of column A1 for residential use and other purposes like A2, B1, and B2.
Usually, the nitrate concentration in surface water is normally low and varied less than $18 \mathrm{mg} / \mathrm{L}$; however, it can also reach high levels because of the agricultural runoff, contamination with human or animal wastes. The concentration often fluctuates following the season and it can increase if the river is fed by nitrate-rich aquifers ( $\mathrm{WHO}$, 2011). The dissolved oxygen values of water matching the column B1 in QCVN 08:2015/BTNMT for irrigation or other purposes requiring the similar quality of water or other purposes like B2. The dissolved oxygen plays an important role to maintain the river's life process and must have a minimum value of about $2 \mathrm{mg} / \mathrm{L}$ to maintain higher life forms (Hach et al., 1997). The phosphate concentration was very high (>0.5 mg/L) and over the standard of column B2 for waterway transport and other purposes with lowquality water requirements. This brings evidence about the presents of pollution in Vinh Long. One-way ANOVA test showed that the value of temperature was significantly different $(p<0.05)$ between dry and rainy seasons, while the other environmental factors were not a significant difference between the two seasons. 
In Vietnam, several investigations and publications are available about the presence of phytoplankton in rivers. Huynh et al. (2011) recorded 128 species of phytoplankton belonging to six divisions of Hau river of which Bacillariophyta contributed the highest species number to phytoplankton composition structure. In a study of phytoplankton composition at Bach Dang river, 116 phytoplankton species were reported wherein Bacillariophyta was also dominant in species number (Nguyen \& Pham, 2011). Some other studies of phytoplankton in Dong Nai river (Pham, 2017), Ba Lai river (Pham et al., 2017), and Vam Co river (Dao \& Bui, 2016) recorded 139, 104, and 290 species, respectively, and Bacillariophyta provided the greatest contributions to phytoplankton composition. According to this, phytoplankton in Vinh Long showed higher species diversity as compared to Hau river, Bach Dang river, Dong Nai river, Ba Lai river, but lower than Vam Co river. However, phytoplankton communities in the mentioned rivers and Vinh Long's water bodies shared the same main phytoplankton groups of Cyanophyta, Bacillariophyta, Chlorophyta, Euglenophyta, with Bacillariophyta being dominant.

In general, the phytoplankton composition in the rainy season was higher than that in the dry season. In contrast, the algal cell density in the wet season was lower than that in the dry season. A one-way ANOVA test showed that the phytoplankton compositions were significantly different $(p<0.05)$ between the dry and rainy seasons, while phytoplankton densities were not a significant difference between the two seasons. The dominant species at these sites in the seasons were Microcystis aeruginosa, Merismopedia glauca, Oscillatoria perornata, Jaaginema sp., Planktothrix agardhii, and Melosira granulata which live in freshwater whereas Coscinodiscus subtilis species originated from the estuary and coastal region. Besides, Microcystis aeruginosa were recorded belonging to toxic algae group which is probably harmful to the aquatic organisms (Nguyen et al., 2007).

There are many studies on the correlation between physicochemical factors and phytoplankton. Pandey et al. (1995) showed a positive correlation between $\mathrm{pH}$, dissolved oxygen, bicarbonate, phosphate, and transparency. Bhat \& Pandit (2005) found a close relationship between physicochemical characters of water and growth and abundance of phytoplankton. They observed the high growth of phytoplankton during summer and very low growth during winter. Salman et al. (2013) and Ishaq et al. (2013) showed a significant positive correlation between phytoplankton with $\mathrm{pH}$, dissolved oxygen, nitrate and significant negative correlation among phytoplankton with BOD. Mousavi et al. (2014), showed a significant correlation between biotic and abiotic factors. In the current study, phytoplankton showed a positive relationship with $\mathrm{pH}$, dissolved oxygen, nitrate in the wet season.

\section{Conclusion}

In the present study, the physicochemical factors and phytoplankton community were seasonally surveyed. The results indicate that the concentration of $\mathrm{pH}$ and nitrate matched the Vietnamese surface water quality national standard (Column A1) whereas the content of dissolved oxygen has reached the value of B1. The average concentration of phosphate exceeded the column B2 of the standard). There are 209 species in the studied areas belonging to six divisions of Bacillariophyta, Chlorophyta, Cyanophyta, Euglenophyta, Chrysophyta, and Dinophyta, of which Bacillariophyta was dominant in species number. The species number of phytoplankton positively correlated with $\mathrm{pH}$, dissolved oxygen and nitrate in the rainy season. The results of this study contribute with essential information on phytoplankton composition and abundance, their correlation with environmental parameters and environmental characteristics in Vinh Long.

\section{Acknowledgments}

We would like to thank Department of Ecology, Institute of Tropical Biology for providing all the necessary facilities for conducting this research work.

\section{References}

[1] APHA. 2005. Standard methods for the examination of water and wastewater. American Public Health Association. Washington DC., USA.

[2] Bhat, S. A., Pandit, A. K., 2005. Phytoplankton Dynamics in Anchar Lake, Kashmir. In: Ecology of Planktons, Ed. Arvind Kumar Daya. Publishing House, Delhi, 190208.

[3] Dao, T. S., \& Bui, T. N. P., 2016. Phytoplankton from Vam Co River in Southern Vietnam. Environmental Management and Sustainable Development, 5(1), 113-125.

[4] Desikachary, T. V., 1959. Cyanophyta. University of Madras. Published by Indian Council of Agricultural Research - New Delhi.

[5] Duong, D. T., \& Vo, H., 1997. Vietnam Fresh Algae. Taxonomy of order Chlorococcale. Agriculture publishing Publishing houseHouse, Hanoi, 503 pp.

[6] Guiry, M. D., \& Guiry, G. M., 2016. AlgaeBase. WorldWide Electronic Publication. National University of Ireland, Galwa. Available: http://www.algaebase.org.

[7] Hach C. C., Klein R. L. Jr., and Gibbs C. R., 1997. Introduction to Biochemical Oxygen Demand. Technical Information Series. Booklet No. 7. Hach Company, U.S.A

[8] Huynh, V. N. Q., Do, T. B. L., \& Pham, T. L., 2011. Biodiversity of phytoplankton in Can Tho bridge area 
of Hau river from 2009 to 2010. In: "Proceedings of the 4th National Scientific Conference on Ecology and Biological Resources", 832-840. Hanoi, Vietnam, October 21, 2011

[9] Ishaq F., Khanna D. R., Khan A., 2013. Physico-chemical and phytoplanktonic characteristics of river Tons at Dehradun (Uttarakhand), India. Journal of Applied and Natural Science, 5(2), 465-474.

[10] Long, S. X., Chen, C., Liu, Z. W., \& Ye, X. Y., 2013. Relationship between phytoplankton and environment factors in Lake Hongfeng. Journal of Environmental Biology, 34(2), 445-449.

[11] Luong, Q. D., \& Phan, T. T. H., 2014. Phytoplankton indices for assessment of trophic status and pollution in Huong river system, Thua Thien Hue province. Journal of Science and Technology, Hue University of Science, 2(1), 93-102.

[12] Mousavi S.A., Soltani M., Kamali A., Shamsaei M., 2014. Phytoplankton diversity and its relation to season and some physicochemical parameters in Karoon 4 Reservoir (Iran). Bulletin of Environment, Pharmacology and Life Sciences, 3(3), 193-200.

[13] Nguyen, L. T. T., Cronberg, G., Annadotter, H., \& Larsen, J. (2007). Planktic cyanobacteria from freshwater localities in ThuaThien-Hue province, Vietnam. II. Algal biomass and microcystin production. Nova Hedwigia, 85(1-2), 35-49.

[14] Nguyen, L. T. T., Cronberg, G., Larsen, J., \& Moestrup, $\varnothing$. (2007). Planktic cyanobacteria from freshwater localities in Thuathien-Hue province, Vietnam. I. Morphology and distribution. Nova Hedwigia, 85(1-2), 1 34.

[15] Nguyen, T. L., Pham, T. N., 2011. Phytoplankton composition at Bach Dang river, Thuy Nguyen district, Hai Phong city from 2006 to 2010. VNU Journal of Science: Natural Sciences and Technology, 27(4), 233238.
[16] Pandey, B. N., Mishra, A. K., Das, P. K. L., and Jha, A. K., 1995. Studies on hydrological conditions of river Saura in relation to its impact on Biological health. In: Recent Research in aquatic environment. Ed. V.B. Ashutosh Goutam and N.K. Aggarwal. Daya Publishing house.

[17] Pham, T. L., 2017. The seasonal and spatial variations of phytoplankton communities in correlations with environmental factors in the Dong Nai river, Vietnam. Journal of Science-Ho Chi Minh University of Education, 14(3), 149-161.

[18] Pham, T. L., Tran, T. N. D., Tran, T. T, Nguyen, T.M.Y, \& Ngo, X. Q., 2017. Seasonal variations of phytoplankton community structure in relation to physico-chemical factors in Ba Lai river, Ben Tre province. Vietnam J. Agri. Sci., 15(5), 631-641 (in Vietnamese)..

[19] Salman, J. M., Jawad, H. J., Nassar, A. J., \& Hassan, F. M., 2013. A study of phytoplankton communities and related environmental factors in Euphrates River (between two cities: Al-Musayyab and Hindiya), Iraq. Journal of Environmental protectionProtection, 4(10), 1071-1079.

[20] Shirota, A., 1966. The plankton of South Vietnamfresh water and marine plankton. Overseas Technical Cooperation Agency, Japan. 462 pp.

[21] Thompson, R.H., 1959. Algae. In: Fresh Water Biology, Ed. Edmondson W.T., University of Washington, Seattle, $115-170$.

[22] Truong, N. A., 1993. Taxonomy of Bacillariophyta plankton in marine water of Vietnam, Science and Technics Publishing House, Hanoi, 314 pp.

[23] Vietnam Ministry of Natural Resources and Environment, 2015. QCVN 08:2015/BTNMT: National technical regulation on surface water quality, Hanoi.

[24] World Health Organization, 2011. Nitrate and nitrite in drinking-water. WHO Press, Geneva, Switzerland. 